https://doi.org/10.22363/2312-8674-2020-19-1-269-276

Рецензия / Book Review

\title{
Babkin, M.A., ed. Konfessional'naya politika Vremennogo pravitel'stva Rossii: sbornik dokumentov [Religious policy of the Russian provisional government: a collection of documents]. Moscow: Politicheskaya Entsyklopediya, 2018. 558 p. (Historia Russica)
}

\author{
Vardan E. Bagdasaryana, Sergey I. Resnyansky ${ }^{\text {a }}$ (reviewers) \\ ${ }^{a}$ Moscow State Regional University; 10A, Radio St., Moscow, 105005, Russia; \\ vardanb@mail.ru; s-r44@yandex.ru
}

\section{Конфессиональная политика Временного правительства России: сборник документов / сост., авт. предисл. и коммент. М.А. Бабкин. М.: Политическая энциклопедия, 2018. 558 с. (Historia Russica)}

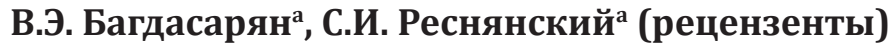 \\ Московский государственный областной университет; \\ 105005, Россия, Москва, ул. Радио, 10 a; vardanb@mail.ru; s-r44@yandex.ru
}

One of the paradoxes in the history of the Russian Revolution of 1917 is the position of the Russian Orthodox Church, which would have had to actively oppose any attempt to overthrow the tsarist government. The theory of Symphonia, presupposed its immanent union with the Orthodox monarchical state; and for the Church, the renunciation of the monarchy was an act of self-denial. Nevertheless, the Church quite easily accepted the February revolution and supported the Provisional Government as a legitimate and God-established authority. The actual basis for understanding this paradox and resolving this paradox through historical analysis is provided by the book Religious Policy of the Russian Provisional Government by M.A. Babkin, Doctor of Historical Sciences, a prominent researcher of the history of religion in Russia and the Russian Orthodox Church. It was published in the ROSSPEN publishing house. The target audience of the publication are specialists in the history of religion and religious policy, as well as all those who are interested in the Russian historical process and have basic knowledge of its development.

The book is presented as a collection of documents, which, due to the acuteness of the subject and public perception of issues of religious faith is justified. The docu-

(C) Bagdasaryan V.E., Resnyansky S.I., 2019

This work is licensed under a Creative Commons Attribution 4.0 International License https://creativecommons.org/licenses/by/4.0/ 
ments, considering the rules of historical criticism, do not allow us to assume the author is taking pro-Church or anti-Church position. On studying them, readers can form their own idea of the development of Church-state relations in Russia of the revolutionary era. However, the outline of the documents does not leave a lot of room for alternative visions objectively convincing of the correctness of characteristics and estimates given by M.A. Babkin in the preface to the edition. In total, the collection includes 252 documents related to the religious policy of the Provisional Government, the basis for the compilation of which were the collections of the State Archive of the Russian Federation (GARF), the Russian State Historical Archive (RGIA), the Russian State Military Historical Archive (RGVIA), official and unofficial publications of state laws, Church regulations and acts, periodicals, memoirs and epistolary sources. In addition to the documents, the book includes the preface in which the author gives his own interpretation of the published materials, and an introduction offering the systematization of the sources used. In addition, he provides a supplement, including, apart from the documents on the issue of the earlier and later epochs, and also includes the chronology of the events of 1917 with the emphasis on the religious policy of the Provisional Government.

Today, interest in religious state policy in historical research is rapidly increasing and is likely to keep increasing. The attitude of state towards religion and religious entities is, in essence, a matter of state ideology. State ideology can be based on a religious platform, and alliances with certain religious entities are often established. Such an alliance with one religion presupposes that there is a dominant or official religion, and such it has a preferential position. Relations with other religions in this logic are either "acceptable" and regionally supported, or "hostile." This is how religious policy was created in the Russian Empire.

But state ideology can also be secular in nature and based on an agnostic or atheistic worldview. In a secular state, the policy towards religious organizations varies: from the approaching to religion as a private sphere up to individual choice, or to the fight against it as a part of an alternative worldview. The former model was implemented under the Provisional Government, and the latter one - in the USSR. However, in this implementation there were deviations and contradictions, which reflected the clash of model principles and political practice, strategy and tactics.

Interest in religious state policy is also determined by its connection with the issue of the identity of state in context of broader society. The positioning of a state in relation to the adoption of a religious platform often serves as the basis for the adoption of a civilizational identity. The positioning of Russia as an "Orthodox state" fixed religious identification in society and connected the affiliation of the Russian ethnic group with Orthodoxy. Accordingly, there arose questions of the identity of peoples professing other religions, which were either resolved in a complex ladder of identification, or were aggravated, leading to periodic conflicts.

The request for research on the history of the religious policy of a state is also connected with the long domination of the econo-centric approach in such studies. In Soviet historiography, in accordance with the theory of class approach, the Church was interpreted primarily as the largest feudal, and the conflicts in Church-state relations as a struggle between two feudal institutions. The methodology of the econo-cen- 
tric analysis was preserved to a large extent in post-Soviet historiography, although it was more often presented in the framework of modernization theory. Meanwhile, it is necessary, as an alternative and disclosure of a different vision, in which religion is not a product of social and economic relations ("superstructure" - in the lexicon of historical materialism), but a set of values and ideas, which are the defining project basis for building a state and society, including a system of economic relations.

Until recently, in the studies on the history of religious policy of Russia there have been chronological gaps. In particular, one such a chronological gap was the period between the February and October revolutions. Despite the limited time frame of this period, its short term and inversiveness, it was an important logical link in the history of religion, the transition from the model of the Russian Empire in the policy of relations with religious organizations to the Soviet one, and most importantly to the modern one.

The modern Russian state also implements religious policy, although it is not institutionalized in the way it was in the Russian Empire, or during the period of the Provisional Government. However, the absence of specialized institutions does not mean that the policy is not implemented. The current model of the religious policy of the Russian Federation, out of all previous historical models, correlates most strongly with the Februarist model. Accordingly, the study of the experience of the religious policy of the Provisional Government is of particular relevance for modern Russia. Bearing in mind the overall negative outcome of the Februarist model implementation, this study should not be built on the principle "do by analogy," but, above all, as be an analysis of strategic mistakes and contradictions. With regard to all these urgent demands, the book written by M.A. Babkin seems to be timely both in scientific and civil terms.

Difficulties in working with materials on the history of religious policy in Russia arise by defining the basic conceptual questions. As is it known, the current legal form of the Russian Orthodox Church only appeared only in 1943, and until that time, there had been no official definition of the largest Russian religious organization. M.A. Babkin lists the names used in the legislative and clerical practice of the Russian Empire, among which are such names unusual for modern parishioners as: "Russian Orthodox Catholic," "Orthodox Catholic Greek-Russian," "Orthodox Greek-Russian," "Russian of Greek law," "Russian Eastern Orthodox" (p. 10). There were even precedents of the simultaneous use of different names in the same document. Such legal uncertainty is quite explainable by the place of the Church in the system of traditional society as a link between man and God, rather than as a legal institution of modern society. Babkin developed this idea further: "The connection between the Russian Empire and the Orthodox Church was primarily sacred, rather than legally formalized" (p. 11).

The author of the book suggests to address the organization simply as the Orthodox Russian Church (ORC). This name emphasizes the connection with the Russian statehood Russia, but it limits the possibilities of an external identity outside the state, which was associated with the markers "Russian," "Greek," "Catholic." Without delving into the advantages and disadvantages of the terminological choice made, we will follow the author further, using this name in the review the author's concept of the ORC (p. 11).

In M.A. Babkin's book, he does not regularly use the concept of "Symphonia of the authorities." which according to other works had the pivotal role in understanding 
the specifics of the Orthodox Russian Church's relationship with the Russian state. In fact, the derogation from the "Symphonia" model was the main historical challenge faced ideologically by both the Church and the state, as each of them followed a path of model substitution. But in this case the author tried a certain amount of detachment as a historian, by not using such concepts as "Symphonia of the authorities," which would bring him closer to a certain value-ideological position, and in this case the position of the Byzantine tradition. At the same time, the concept "Symphonia" as it follows from the materials given in the book, and in supporting documents did not exist in the corresponding era. It was forced out discourse, and in this case the author followed how the term was used in historical sources. The introduction of the category that was absent in the discourse of may have led to the deformation of the described historical epoch under the topology of other epochs.

To characterize the position of the ORC in the Russian Empire, the author uses the definition of "dominant Church" (p. 11). At the same time, it is emphasized that it was not a public institution, like it was in Protestant and Catholic Europe. In Russia, the Church was part of the unified state structure. The state assumed a number of purely religious functions, and at the same time the ORC assumed certain functions of the state (p. 11-13). In this sense, the issue of Church-state relations traditional for modern scientific discussion is not quite correct in the sense that the separation of Church and state was simply different in Russia. This division was carried out after the February revolution, when the ORC and the state were no longer a single entity, but two institutions with their own interests and their own value agenda, as was the case in the West.

The author of the book points to the potentially conflicting sides of the situation of the ORC in the Russian Empire, which shed some light on the position of the Chruch hierarchy before the February Revolution. On the one hand, there was oppression by state control, which was expressed in the establishment of a controlling institution of a secular person over the Synod, the Chief Procurator. Certainly, the Chief Procurator acted on behalf of the Tsar, who was also sacred, but oppression by bureaucratic interference on the part of the clergy should not be excluded. The Church Council formed by the Provisional Government was intended to solve this problem through the restoration of the institution of the Patriarchate. M.A. Babkin characterizes this plan as an attempt to establish a "monarchy in the Church" pointing out that despite the declarations on the autonomy of religious organizations, the Provisional Government might not have legitimized this decision. As is known, the election of the Patriarch in the ORC took place under the Bolsheviks in November 1917 (p. 39).

Another potential conflicting issue was the Church property. M.A. Babkin indicates that by having no certain legal status, the ORC was not the owner of real estate (p.11). The property's owner was the Orthodox state, headed by the Tsar who combined both secular and religious functions. The autonomization of the religious existence of the ORC under the Provisional Government provided a positive solution to the issue of property in the Church's favor. Certainly, the issue of the Church property in the context of the reforms of religious policy does not give a clear answer about the impact of this factor on the position of the ORC during the revolutionary transformations; but the very 
statement of this problem opens up new aspects in the understanding of the historical process of the ORC's development.

In the USSR, the policy of state to ORC was determined, by the Decree of January 20, 1918 on the separation of Church and State, a provision which was further established in subsequent Soviet constitutions. The provision on the separation of church and state had been previously contained in the French Constitution, which became an example of the most uncompromising legislative consolidation of the principles of secularity. To define the religious policy of the Provisional Government, M.A. Babkin uses the definition of "alienation" instead of the concept of "separation" (p. 13).

The ORC distanced itself from the state but did not completely separate itself from it. It was still a religious organization that retained certain, though limited, privileges as the "dominant Church" of the Russian Empire; just as it experienced all the costs of state intervention (p. 27-28). In addition, there remained the retention of the Church's registration of marriages; and the legislation still treated certain items of Christian churches as "sacred" or "consecrated in worship." The Holy Governing Synod still functioned, and the posts of Chief Procurator of which were occupied by secular figures - V.N. Lvov and A.N. Kartashev (p. 22, 26-27, 176). The definitions of the Synod were approved by the Provisional Government and published in the Collection of Laws and Orders of the Government. It was the Provisional Government, rather than the ORCwhich took the decision to grant autocephaly to the Orthodox Georgian Church with the Mtskheta Catholicos at its head and to grant it Transcaucasian parishes, which testified to the fact that the ORC was still considered as part of the state system (p. 24-25, 263-265, 267-269). Later, Patriarch Tikhon would strongly condemn this decision, which would lead to the severance of inter-Church communication between the ORC and the Georgian Church up to 1943.

The author reveals the religious policy of the Provisional Government as internally contradictory, which provides reasons understanding for its failure in new ideological circumstances. On the one hand, it was stated about the non-religious nature of the state, freedom of religion, refusal of state interference in religious life, was interpreted through the autonomous law of religious communities and private human rights. But at the same time, the Provisional Government did not want to lose control over the Church; it continued to use the structures of the ORC for its own interests, and it was not ready to delineate its functions. Probably, over time, the vector towards secularization would have manifested itself more clearly, but as we know, history did not provide the Provisional Government with such a chance. The general conclusion to which M. A. Babkin comes to in assessing the policy of the Provisional Government in relation to the ORC is as follows:

The documents of the collection indicate a certain inconsistency of the religious policy of the Provisional Government. On the one hand, the authorities spoke about the "non-religious' nature of the state: promising the equality of all religions, the autonomy of the existence of secular and religious spheres, the material support of all religions by the state, and the removal of all functions of state bodies from the clergy, etc. On the other hand, the institution of the state Church remained largely unchanged, and the ORC retained a number of its privileges. In general, the Provisional Government failed to implement 
the principle of freedom of conscience. The declared equality of religions was not established (for example, not all religions received allocations from the state); the ORC retained its status as the 'dominant' Church enshrined in pre-revolutionary legislation. Moreover, the government protected the rights of the state Church, and the government did not plan the 'separation' of the ORC from the state. Moreover, in the matters 'external' Church administration, the Provisional Government not only considered itself vested with essentially the same rights as the Russian Empire, but also acted accordingl" (p. 36-37).

While the activities of the Holy Governing Synod were traditionally regarded as the most important institution in the system of state administration and the implementation of religious policy in the Russian Empire, the functions of the institution that was directly related to the religious policy - the Department of Religious Affairs of Foreign Confessions - gets incomparably less attention. The very existence of the Department that defines non-Orthodox religions - Catholics, Protestants, Muslims, Jews, Lamaists, Armenian-Gregorians as foreign religions - and is important evidence of how the identity and ideology of the Russian state framed religious life. The attitude to these religions was diversified and determined not least by the vicissitudes of Russia's foreign policy. Its conflicts with states, traditionally associated with the corresponding religious community, led to the tightening of the screws against the flock of those religions in the country (p. 14-19).

The indisputable advantage of the collection of documents prepared by M.A. Babkin was the demonstration of combining two directions within the framework of a single religious policy of Russia: 1) in relation to the ORC and 2) its relation to non-Orthodox and Gentiles. The collection is structured according to the religious organizations, which allows us to see the specification of the religious policy of the Provisional Government for each of them: General religious lawmaking (p. 57-171); Russian Orthodox Church (p. 172-259); Georgian Church (p. 259-279); Old Belief (p. 279-297); Roman Catholic Church (within it there are documents on Uniates) (p. 297-378); Armenian Apostolic Church (p. 378-383); Evangelical Lutheran Church (p. 384-401); "free believers" by subsections - Mennonites, Skoptsy, Baptists, Dukhobors (p. 402-416); Gentiles by subsections - Muslims, Jews, Karaites, Buddhists (p. 416-438). In terms of the volume, the emphasis in the collection is placed on Christian religions and in comparison, with which the volume of documents on Muslims, Jews and Buddhists is considerably inferior. But even in this case, the author followed the basic outline of the religious policy and law-making of the Provisional Government. He either did not get around to the Gentiles or lacked the determination to break the existing system of relations due to the likely threat of large-scale religious conflicts. Thus, according to M.A. Babkin, the Provisional Government planned to reform the Department of Religious Affairs of Muslims, but postponed it, and eventually never did it (p. 35). Of interest is the attempt to develop texts of oaths for the service of the Russian state with the reflection of the peculiarities of each religion, which received coverage in the documents $(21-22,109-110,283,430)$.

In general, on the basis of the documents presented in the collection it can be concluded that non-Orthodox and Gentiles legally benefited from the reforms. Already on March 20, 1917, the government issued a decree "On abolition of religious and national restrictions" which expanded opportunities for religious communities and removed 
the restrictive provisions of civil law against non-Orthodox and Gentiles. At the same time, the state approved equality of all religions before the law (p. 22-23, 60-72). However, regarding the specificity of religious cults, of organizing religious communities, of the nature of relations with other religions, the ORC raised many questions that caused difficulties in the practical implementation of the previously stated principle. As a result, as the documents show, the reform was stalled and never finished, and promoted a number of contradictions that manifested themselves particularly acutely during the Civil war. One can hardly consider as a deliberate step, the practice of creating military units on the basis of religious principles (in particular, the Catholic and Muslim divisions), was both initiated within the religious policy of the Provisional Government and reflected in the peer-reviewed thematic collection of the documents.

The documents selected in the book make it possible to definitely identify the Februarists as supporters of a secular model of society. In various structures of the Provisional Government there were believers and even Church figures, but in general the vector of the February revolution was definitely a vector of secularity. This is most evident in the documents presented in the field of education. Despite the protests from the Holy Synod, parochial schools were withdrawn from the control of the ORC and transferred on a general basis to the sphere of control of the Ministry of Education. At the same time, there was no corresponding transfer of religious schools of other confessions. Thus, only Orthodox religious education was eliminated (p. 36, 199-201, 207-210).

Teaching of the Religious Education at school ceased to be compulsory. The local Council of the ORC opposed this decision and adopted a provision that still supported the obligation to teach the religious education in schools, a provision which was discordant with the Provisional Government bill (p. 160-163). M.A. Babkin gives the following opinion of the conflict:

By proclaiming the transfer of parochial schools and the abolition of compulsory teaching of the Religious Education in all primary and secondary schools, the state actually abandoned the function of religious education of children and youth through Religious Education (p. 37).

The documents collected in the book empirically explain the reasons for the defeat of Februarism in Russia in 1917. The Provisional Government lost, above all, ideologically. The ideological and worldview platform that it proposed proved to be internally contradictory and could not eventually captivate the majority of the country's population. The new government had neither the ideological and worldview certainty on which the Orthodox state had previously been built, nor the platform on which the "Orthodox project" eventually would be formed in the future. The documents on the history of the religious policy of the Provisional Government collected by M.A. Babkin illustrate the ideological and, as a consequence, the political inconsistency of the Februarist regime, and how this inconsistency eventually led to its collapse.

Рукопись поступила: 5 Августа 2019 г.

Sibmitted: 5 August 2019 


\section{Информация об авторах / Information about the authors}

Багдасарян Вардан Эрнестович, доктор исторических наук, декан факультета истории, политологии и права, заведующий кафедрой истории России средних веков и нового времени Московского государственного областного университета.

Реснянский Сергей Иванович, доктор исторических наук, профессор кафедры истории России средних веков и нового времени Московского государственного областного университета.
Vardan E. Bagdasaryan, Doctor Istoricheskikh Nauk [Dr. habil. hist.], Dean of the Faculty of History, Political Science and Law, Head of the Department of Russian History of the Middle Ages and New Time, Moscow State Regional University

Sergey I. Resnyansky, Doctor Istoricheskikh Nauk [Dr. habil. hist.], Professor of Department of Russian History of the Middle Ages and New Time, Moscow State Regional University. 